University of Nebraska - Lincoln

DigitalCommons@University of Nebraska - Lincoln

Faculty Publications -- Department of English

English, Department of

Winter 1981

\title{
The Myth of Lesbian Impunity Capital Laws from 1270 to 1791
}

Louis Crompton

University of Nebraska - Lincoln

Follow this and additional works at: https://digitalcommons.unl.edu/englishfacpubs

Part of the English Language and Literature Commons

Crompton, Louis, "The Myth of Lesbian Impunity Capital Laws from 1270 to 1791" (1981). Faculty Publications -- Department of English. 59.

https://digitalcommons.unl.edu/englishfacpubs/59

This Article is brought to you for free and open access by the English, Department of at DigitalCommons@University of Nebraska - Lincoln. It has been accepted for inclusion in Faculty Publications -- Department of English by an authorized administrator of DigitalCommons@University of Nebraska - Lincoln. 


\title{
THE MYTH OF LESBIAN IMPUNITY
}

CAPITAL LAWS from 1270 to 1791

Louis Crompton, $\mathrm{PhD}$

\begin{abstract}
The standard history of antihomosexual legislation states that lesbian acts were not punished by medieval or later laws. This essay challenges this view by documenting capital laws since 1270 in Europe and America. A major influence was Paul's condemnation in Romans $I, 26$. By 1400, the lex foedissimam, an edict of the Emperors Diocletian and Maximianus, issued in 287, was interpreted to justify the death penalty. Executions took place in Germany, France, Italy, Switzerland, and Spain. A brief survey of presently known male deaths in Europe and the Americas, which number about 400, also is included. This study draws on canon law and the commentaries of such jurists as Cino da Pistoia, Saliceto, López, Gómez, Farinacio, Cotton, Carpzow, Sinistrari, de Vouglans, and Jousse. It also discusses the records of a German trial of 1721, published elsewhere in this issue, that also led to the execution of a woman.
\end{abstract}

Little has been written about lesbianism and the law from a historical point of view. Indeed, I am not aware of a single modern essay on the subject, and even brief references are comparatively rare. ${ }^{1}$ In 1955 , Derrick Sherwin Bailey, in what is still the standard study of early antihomosexual legislation, wrote categorically that lesbian acts were "ignored by both medieval and modern law." 2 As we shall see, this statement is clearly wrong. In making it, Bailey was generalizing in an unwarranted fashion from the situation in England. It is true that England's traditional "buggery" statute, first enacted in 1533 under Henry VIII, used terminology (still in force until 1967) that was not interpreted as criminalizing relations between women. American legal tradition until the twentieth century tended to follow English standards, with one remarkable exception to be noted later. In Europe before the French revolution, however, notably in such countries as France, Spain, Italy, Germany, and Switzerland, lesbian acts were regarded as legally equivalent to acts of male sodomy and were, like them, punishable by the death penalty. On occasion, executions of women were carried out. The purpose of this paper is to illuminate

Dr. Crompton is in the Department of English, University of Nebraska, Lincoln, Nebraska 68588. He wishes to express his gratitude to Dr. Stanley Vandersall for valuable help in translating several of the Latin sources. 
this tradition of capital legislation, to trace its sources, and to document some of the deaths by hanging, burning, drowning, and beheading that did in fact take place. It also is intended to serve as an introduction to the records of a remarkable trial, conducted at Halberstadt, Germany, in 1721, which are translated into English for the first time by Brigitte Eriksson in this issue of the Journal of Homosexuality.

It is well known that the death penalty for male homosexuality can be traced back in Judeo-Christian tradition to Leviticus 20:13. The Jews of ancient times, however, do not seem to have looked on lesbianism as a serious offense. There is no reference to it as a crime in the Old Testament. In the Babylonian Talmud, Rabbi Huna (who died in 296 A.D.) is quoted as ruling that "Women who practice lewdness with one another are disqualified from marrying a priest." But even this mild sanction is rejected by the Talmud, which prefers the view of Rabbi Eleazar (circa 150 A.D.), who argued that such a relation was no bar to priestly marriage, since "the action is regarded as mere obscenity." 3

One may legitimately ask why, when Judaism looked on male homosexuality with such deadly hatred, it was comparatively indifferent to lesbianism. The most likely explanation is that male homosexuality was a religious practice of the "holy men" (kedeshim) of the Canaanite cults which were competing with orthodox Jahwism, while the correspondent "holy women" (kedeshoth) of these cults were not lesbians but women who engaged in heterosexual relations as part of their religion. Thus, the King James translation of Deuteronomy 23:17 reads, significantly, "There shall be no whore (kadeshah) of the daughters of Israel, nor a sodomite (kadesh) of the sons of Israel." The result of this religious animosity seems to have been the proscription of male, but not female, homosexuality, and the incorporation of the death penalty into the Levitical code, probably during the sixth century B.C., in a form applicable only to men. ${ }^{4}$

In Romans I, 26, however, St. Paul condemns women "who did change the natural use into that which is against nature." Eventually, as time passed, this animadversion of Paul's was to have fateful consequences for the legal status of lesbians in Christendom. Nevertheless, the first Roman Christian Imperial laws explicitly penalizing homosexuality, the edicts of Constantine and Constans in 342 A.D. and of Theodosius in 390 A.D., use language that specifically threatens death to men only, though, as we shall see, the scope of the law of 342 A.D. (cum vir) was subsequently broadened by medieval jurists to cover women. Both these laws ultimately were incorporated in the Codex Justinianus. A later law, Justinian's Novella 77 of 538 A.D., criminalizes "acts contrary to nature;" but Novella 141, which was issued six years later, speaks only of "the defilement of males" (de 
stupro masculorum). ${ }^{5}$ We do not know how Novella 77 was construed, but we have as yet no evidence that it was interpreted to include lesbianism.

The earliest secular law I am aware of that seems to make explicit reference to sexual relations between women appears in a French code called $\mathrm{Li}$ Livres di jostice et de plet, usually dated about 1270, which derives from the district of Orleans. This compilation contains the following penalties:

22. He who has been proved to be a sodomite must lose his testicles. And if he does it a second time, he must lose his member. And if he does it a third time, he must be burned.

23. A woman who does this shall lose her member each time, and on the third must be burned. (Feme qui le fet doit a chescune foiz perdre membre et la tierce doit estre arsse. $)^{6}$

Conceivably, the formula "perdre membre" in 23 might refer to the loss of an arm or leg; however, it is identical with that used in 22, where the context indicates that the man's penis is meant. Apparently this law called for the infliction of a clitorectomy, but it is difficult to imagine how this operation could be performed twice. Rarely has a law aimed primarily at male offenders been more grotesquely adapted to women. Surprisingly, Bailey translates these laws but takes no note of their relevance to lesbians.

The idea of lesbianism as a capital crime had certainly taken root in the popular imagination by this time. This is attested by a French romance presumed to have been written before the early fourteenth century, in which two women are threatened with burning. It is the tale of Princess Ide, an extension of the Huon of Bordeaux legend. Because of her military exploits, the Princess Ide, who has fought disguised as a man, is commanded by the Emperor to marry his daughter. Though the women, in the words of the sixteenth-century English translation by Lord Berners, pass their time in nothing more than "clyppinge and kyssyinge," the Emperor, when he discovers Ide's true sex, "wold not suffre suche boggery to be vsed," and commands that "bothe you and my doughter shall be brent." Ide and her lover are saved from the flames only by a miracle of the Virgin, who transforms Ide into a man in response to her prayers. ${ }^{\text {? }}$

By this time the theory that lesbianism was a heinous crime, fully as evil as male homosexuality and equally deserving of the death penalty, obviously had replaced Jewish tolerance. How are we to account for this change of attitude? Basically, it seems to have occurred as a development in the logic of Christian moral theology, as a rationalized conception of natural law came to replace earlier cultic anxieties. The 
broader idea of crimes against nature, criminal because they provided sexual pleasure without procreation, superseded the earlier cultic offense of male sodomy. In extending the death penalty for sodomy to women, St. Paul's condemnation in Romans was, undoubtedly, of paramount importance. Though modern scholars have commented on the ambiguity of his language, which might conceivably refer to women who engaged in heterosexual sodomy,$^{8}$ a study of Paul's early commentators shows that they did, indeed, regard the women who "changed the natural use"' as lesbians. For example, the most influential of the Greek Fathers, St. John Chrysostom, preaching on Romans I, 26, 27, at Antioch about 390 A.D., paraphrased the passage by declaring that, in Paul's day, "even women again abused women, and not men only. And the men stood against one another, and against the female sex, as happens in battle by night." So the devil went about "to destroy the human race." "A Latin commentary of the same period, attributed to St. Ambrose, says of Paul, "He testifies that, God being angry with the human race because of their idolatry, it came about that a woman would desire a woman for the use of foul lust." ${ }^{10}$ Writing at the beginning of the twelfth century, St. Anselm of Canterbury explained Paul's sentence: “Thus women changed their natural use into that which is against nature, because the women themselves committed shameful deeds with women." 11 A few years later Peter Abelard glossed Paul's reference to women's acts against nature even more forcefully: "Against nature, that is, against the order of nature, which created women's genitals for the use of men, and conversely, and not so women could cohabit with women." 12 Most of the numerous explications of Paul's Epistles do not, of course, deal with the sexology of Romans I, 26; however, an extensive search through early commentaries has as yet yielded no examples of commentators who read the passage in other than a lesbian sense. ${ }^{13}$

It is not surprising, therefore, to find that lesbianism was singled out as a sin in some early penitentials, notably that of Theodore of Tarsus, Archbishop of Canterbury, which dates from about 670 A.D., and of the Venerable Bede, compiled before 734 A.D. ${ }^{14}$ Two works that were to become definitive guides to Christian moral theology also set lesbianism morally on a par with male sodomy. Gratian's Decretum of 1140 remained a standard work of canon law until 1917. It incorporated a passage from the Contra Jovinianam ascribed to Augustine: "Acts contrary to nature are in truth always illicit, and without doubt more shameful and foul, which use the Holy Apostle has condemned both in women and in men, meaning them to be understood as more damnable than if they sinned through the natural use by adultery or fornication." 15 Though his language, like Paul's, is potentially ambiguous, it was undoubtedly construed, as was his, to refer to les- 
bianism. The other medieval authority, whose influence on Catholic moral thinking has remained paramount down to the present day, was St. Thomas Aquinas. The Summa Theologica, written in 1267-1273, describes four forms of "unnatural vice." The third of these is distinguished as "copulation with an undue sex, male with male, or female with female, as the Apostle states (Rom. I, 27): and this is called the vice of sodomy" (Pt. II-II, Qu. 154, Art. 11). ${ }^{16}$ Thus Aquinas set his seal on the received interpretation of Paul and placed lesbianism unequivocally in the same moral category with male relations. Canon law and Catholic moral theology had a very considerable influence in shaping medieval secular law. Some Carolingian kings actually promulgated the canons of various church councils as laws of the realm. ${ }^{17}$

Another important influence in the Middle Ages was the revival of Roman law, which began in Bologna in the eleventh century. The writings of jurists who made it their study soon came to have weight throughout Europe. Two commentators of this school were regularly cited by later authorities to justify the punishment of lesbians. These were Cino da Pistoia, poet and friend of Dante, and Bartholomaeus of Saliceto, who taught at Bologna at the end of the fourteenth century. Cino, in the Commentary on the Code of Justinian which he published in 1314, interpreted an imperial edict of 287 A.D. as referring to lesbianism. This law, issued jointly by the Emperors Diocletian and Maximianus, was eventually incorporated as law 20 of the lex Iulia de adulteriis (book 9, title 9), the part of the Code dealing with sexual offenses. Diocletian and Maximianus made numerous additions to the lex Iulia that refine and delimit earlier laws. The lex foedissimam, as it was called from its opening word, appears to have been formulated to protect the rights of rape victims by removing them from the class of unchaste women (prostitutes, etc.) whom Romans of the upper ranks were legally forbidden to marry. It seems unlikely that the first part of the law, which is entirely vague in its reference to female sexual misconduct, was designed to create any new offenses or to be used in place of earlier statutes. Rather it merely seems to imply that older laws were not to be revoked, except for violated women. The language of the law suggests that a controversy over the rights of such women (or of the men who sought to marry them) had arisen in the courts and that the Emperors wished to confirm a decision in their favor. Since, however, this was the Roman statute that medieval jurists used to place lesbians in the shadow of the stake and the gallows for at least five centuries, its text is perhaps worth quoting in full:

The laws punish the most foul wickedness (foedissimam nequitiam) of women who surrender their honor to the lusts of others, although not the blameless will of those who are 
defiled by violence, since it was properly decreed that they should be of inviolate reputation and that marriage to them should not be forbidden to others. ${ }^{18}$

But whatever was intended in the third century, Cino's gloss on the foedissimam unambiguously interprets the law as applying to lesbians: "This law can be understood in two ways: first, when a woman suffers defilement by surrendering to a male; the other way is when a woman suffers defilement in surrendering to another woman. For there are certain women, inclined to foul wickedness, who exercise their lust on other women and pursue them like men." 19 Cino cites no prior authorities; only further research among the early glossators will show whether he was echoing an established tradition or inaugurating a new one.

Bartholomaeus de Saliceto, in his Lectures of 1400 , refers to an earlier gloss on the lex foedissimam (which may well be Cino's) in applying the law to the defilement of women by women. He then goes a step further by definitely prescribing the death penalty, which he justifies by a cross-reference to cum vir (book 9, title 9, law 31), which provided that male homosexual acts be punished by the "avenging sword." 20 Saliceto's glosses on these edicts remained standard references until the eighteenth century. Since, according to the Roman tradition, the opinions of eminent jurists often had the force of law, it would have been possible, by using these dicta, to argue for the death penalty for lesbianism even in parts of the continent with no national or local legislation. In Italy the influence of Roman law was all-pervasive; in Spain the Partidas were largely based on it; in France the kings fostered its revival; and even in Germany, after 1500, and Scotland, after 1600, it enjoyed remarkable, if belated, triumphs. ${ }^{21}$ Thus, throughout the continent, lawyers trained in Roman law and imbued with LeviticalPauline principles were encouraged to write provisions for the killing of lesbians into the civic, regional, and imperial codes they drafted during the late Middle Ages and the Renaissance.

Were such executions carried out? Derrick Sherwin Bailey, writing in 1955, systematically minimized the effect of church-inspired capital laws for sodomy. More recently, in his otherwise admirable study, Sexual Variance in Society and History, Vern Bullough has uncritically followed Bailey's conclusion. ${ }^{22}$ Evidence now has accumulated, however, to show that a significant number of executions of men and women did in fact take place. Henry Lea noted several dozen burnings of convicted men by the Inquisition in Spain. ${ }^{23}$ G. Ruggiero has documented the execution of sixteen young noblemen in Venice in 1406-1407 24 and Clark Taylor has recorded fourteen burnings in Mexico City in $1658 .^{25}$ E. W. Monter's study of sixteenth and seventeenth century Switzerland records another twenty-eight deaths. ${ }^{26}$ Drawing on an 
earlier study by Van Römer, I have published the names and occupations of sixty men executed in Holland in 1730 and 1731, and from statistical tables issued by the British government have established that an equal number of hangings took place in Britain during the years 1806-1835. ${ }^{27}$ Arthur Gilbert, by examining records of courts martial, has added another forty-five hangings in the British navy from 1703 to 1829. ${ }^{28}$ Claude Courouve's forthcoming Archives de l'homosexualité will document thirty executions in France from 1317 to $1783,{ }^{29}$ however, a new survey of unpublished appeal records shows seventy-seven death sentences confirmed by the Parliament of Paris during the years 1565-1640, about eight times the number of executions Courouve's studies of published sources have revealed for the period..$^{30}$ No studies I know of exist for Scandinavia, Russia, or for German or Italian citystates other than Venice and Ferrara. My research at present substantiates more than 400 deaths in eight countries but I do not doubt this will prove to be only a small fraction of the total.

The earliest execution I have been able to discover in Christian Europe is that of John de Wettre, "a maker of small knives," who was condemned at Ghent on September 8, 1292, and ''burned at the pillory next to St. Peter's." Executions of women, of course, are much rarer, but Rudolph His in Das Strafrecht des deutschen Mittelalters records the drowning of a girl at Speier in 1477 "for lesbian love." ${ }^{32}$ In the sixteenth century, Antonio Gómez tells us that two Spanish nuns were burned for using "material instruments." ${ }^{33}$ In France, Jean Papon describes the trial and torture of two women, Françoise de l'Etage and Catherine de la Manière, at Bordeaux in 1533. They were, however, acquitted for insufficient evidence. ${ }^{34}$ Henri Estienne mentions a woman from Fontaines who disguised herself as a man, married another woman, and was burned alive about 1535 after the discovery of the "wickedness which she used to counterfeit the office of a husband." ${ }^{35}$ Montaigne, in his Diary of a journey to Italy, tells the story of a hanging in the Marne district in 1580:

Seven or eight girls around Chaumont en Bussigni secretly agreed, some years ago, to dress themselves up as men, and so to continue their life in the world. One of them came to this place, Vitry, under the name of Marie, gaining her livelihood by being a weaver, a wellbehaved young man who made friends with everybody. He engaged himself at the said Vitry to a woman who is still alive, but for some disagreement which arose between them, their bargain went no further. Afterwards, having to go to the said Monter-en-Der, still earning his livelihood at the said trade, he fell in love with a woman whom he married and lived four or five months with her, to her satisfaction, according to what they say, but, having been recognized by somebody from the said Chaumont, and the matter being brought before justice, she was condemned to be hanged, which she said she would rather endure than to return to the state of a girl; and was hanged on the charge of having, by illicit devices, supplied the defects of her sex. ${ }^{36}$ 
Hanging, or some other form of capital punishment, would have been sanctioned, as far as I have been able to determine, by the generality of the Renaissance jurists, and various codes of that period support this view. Section 116 of the Constitutions of the Holy Roman Emporer Charles V, issued in 1532, provided that "if anyone commits impurity with a beast, or a man with a man, or a woman with a woman, they have forfeited their lives and shall, after the common custom, be sentenced to death by burning. "37 Other European communities, less extensive than the domains of Charles, also adopted laws that made lesbianism explicitly an offense. An instance of this was a macabre provision in the statutes of the Italian town of Treviso, near Venice, which, taking both sexes into account, provided that

If any person (leaving the natural use) has sexual relations with another, that is, a man with a man if they are fourteen years old or more, or a woman with a woman if they are twelve or more, by committing the vice of sodomy-popularly known as "buzerones" or "fregatores" - and this has been revealed to the city magistrates, the detected person, if a male, must be stripped of all his clothes and fastened to a stake in the Street of the Locusts with a nail or rivet driven through his male member, and shall remain there all day and all night under a reliable guard, and the following day be burned outside the city. If, however, a woman commits this vice or sin against nature, she shall [also] be fastened naked to a stake in the Street of the Locusts and shall remain there all day and night under a reliable guard, and the following day shall be burned outside the city. ${ }^{38}$

The Spanish seem to have been preeminent in Renaissance Europe as specialists on the subject of lesbianism and the law. The most important medieval Spanish law on sodomy was Title 21 of the last book of Las Siete Partidas, compiled under the direction of Alfonso $\mathrm{X}$ about 1265. Ley II of Title 21 prescribes the death penalty for men, but the standard gloss on the Partidas, prepared by Gregorio López for the Salamanca edition of 1555, argues at length that the law applied to women as well as men. López cites St. Paul, the gloss of the lex foedissimam, Saliceto, and Angelico de Aretino: "Women sinning in this way are punished by burning according to the law (pragmatica) of their Catholic Majesties which orders that this crime against nature be punished with such a penalty, especially since the said law is not restricted to men, but refers to any person of whatever condition who has unnatural intercourse." ${ }^{39}$ López, however, notes the minority opinion of Abulensis, ${ }^{40}$ according to which lesbian acts were not as heinous as acts of male sodomy since women were by nature more passionately responsive than men. Moreover, male couples "perfect" the act and "defile the image of God," whereas women, though they may suffer from disordered wills, cannot "pollute" each other, presumably because they were not capable of penetration and emission. On these 
grounds, Abulensis held that lesbian acts might sometimes be punished with penalties short of death. This view seems to have influenced López's contemporary, Antonio Gómez, who was much cited in later continental sources. Gómez lays down the principle that "if any woman act the part of a man with another woman ... both are said to commit the crime of Sodom against nature and must be punished with the prescribed penalty." ${ }^{\prime 1}$ Gómez cites both Romans I, 26 and St. Thomas II-II, Qu. 154, Art. 11 as authorities for this position. He then distinguishes two possibilities. First, "if a woman has relations with another woman by means of any material instrument," they must be burned. Second, "if a woman has relations with any woman without an instrument," a lighter penalty is permissable. He tells us of such a prosecution in Granada where the women were whipped and sent to the galleys.

Russian legal tradition was also severe. Gregory Karpovich Kotoshikhin, summarizing capital crimes in his On Russia in the Reign of Alexis Mikailovich (i.e., shortly after 1645), records that "females are put to death as follows: for blasphemy and church robbery and sodomy they are burned alive." 42

Catholic and Orthodox Europe, however, were not the only parts of the continent that favored severe punishment. Though lesbianism was ignored by English law, this was not the tradition in other protestant countries, such as Germany and the Calvinist cantons of Switzerland. E. W. Monter notes that the executions which followed the triumph of the Calvinist party in Geneva in 1555 included the case of a woman who was put to death in 1568 . The woman originally had been arrested for fornication, a charge which she denied in a fashion her judges found blasphemous. Later she confessed that she had indulged in sapphism at an earlier date. She was convicted of all three crimes and drowned. Monter mentions also a woman named J. Cuasset who was tried on September 10, 1635, at Fribourg. Her fate, however, is unknown since the sentences meted out at the Fribourg trials apparently have not survived.

The same Puritanism that animated the Swiss in the sixteenth and seventeenth centuries had effects elsewhere. When settlers in New England drew up their first code of law, they seriously considered breaking with English tradition by making lesbianism a capital crime. In 1636 the Rev. John Cotton presented to the General Court of Massachusetts a body of laws, article 20 of which provided that "unnatural filthiness [is] to be punished with death, whether sodomy, which is a carnal fellowship of man with man, or woman with woman, or buggery, which is a carnal fellowship of man or woman with beasts or fowls. " 43 It appears that these laws never were formally adopted by the court. In New Haven, however, a very elaborate and unusual law 
passed in 1655 provided that "If any man lyeth with mankinde, as a man lyeth with a woman, both of them have committed abomination, they both shall surely be put to death. Levit 20.13. And if any woman change the naturall use into that which is against nature, as Rom. I, 26 , she shall be liable to the same sentence, and punishment." ${ }_{44}$

This law was superseded a few years later when New Haven became part of Connecticut, and no record has yet come to light of any rigorous penalties being applied to women in America. The one episode noted so far resulted in a lenient sentence. ${ }^{45}$ The records of the General Court of New Plymouth for March 8, 1648/49, describe the arraignment of "the wife of Hugh Norman, and Mary Hammon, both of Yarmouth, for luede behauior each with other vpon a bed." Nineteen months later, on October 2, 1650, the court, taking into account "diuers lasiuious speeches by her allso spoken," sentenced Mrs. Norman "for her vild behauior in the aforsaid particulars, to make a publick acknowledgment, so fare as conveniently may bee, of her vnchast behauior, and haue allso warned her to take heed of such cariages for the future, lest her former cariage come in remembrance against her to make her punishment the greater." ${ }^{46}$

The question of exactly what physical relations between women constituted punishable sodomy was raised by Luigi-Maria Sinistrari d'Ameno in his erudite and detailed treatise, De Delictis et Poenis, published in 1700. Sinistrari takes the radical position that penetration by an instrument should not be counted as legal sodomy. For Sinistrari, sodomy required fleshy union. If the insertion of a finger into the vagina was not a sodomitical act, why should it be a crime to insert an inanimate object? Yet Paul and Aquinas must have had some specific deed in mind when they equated female and male sodomy. Sinistrari thinks that the solution lies in the unusual features of some female anatomies. He cites the Danish anatomist, Kaspar Bartholin, to the effect that among Ethiopian women the clitoris protrudes and is cauterized in childhood to prevent its development, which would hinder male entry. He also notes a statement attributed to Galen that the ancient Egyptians circumcised their women to prevent lesbianism. He thinks some European women have similarly overdeveloped clitorises and gives a number of medical histories, including that of a noblewoman who was supposed to have penetrated a twelve-year-old boy. In cases of suspected lesbianism an enlarged clitoris should be a presumption of guilt and justify torture. Sinistrari implies that accusations of lesbian sodomy should be discountenanced unless such anatomical irregularities are found. But women who penetrate men or other women with such unusual organs should be burned. ${ }^{47}$ 
The researches of Claude Courouve into trials in France in the eighteenth century have identified a number of trials of males for sodomy but none for lesbianism, though, as we have seen, some took place earlier. French authorities, however, were still of the opinion that lesbian acts were as culpable as male sodomy and open to the same penalties. For example, Pierre-François Muyart de Vouglans in Chapter X ("Of Sodomy") of his Institutes au droit criminel of 1757 tells us that "This crime, which derives its name from that abominable city, which is mentioned in Holy Scripture, is committed by a man with a man, or by a woman with a woman." As to the penalty, he is similarly explicit. "The law cum vir 31. of the code de adult. ordains that those who fall into this crime should be punished by being burned alive. This penalty which our jurisprudence has adopted is equally applicable to women as to men." 48 This view was current until the very eve of the Revolution. Daniel Jousse, in his Traité de la justice criminelle de France (1777), expresses as lively a horror of sodomy as any Father of the Church, and devotes a special section in Chapter XLIX ("Of Sodomy, and other crimes against nature") to "Women who corrupt one another." "The crime of women who corrupt one another is regarded as a kind of sodomy, if they practice venereal acts after the fashion of a man and a woman, and is worthy of capital punishment (la dernière supplice) according to the law foedissimam, C. ad L. Jul. de. adulter.; and such is the common opinion of the authorities. " 49

The belief that lesbians should expiate their crimes on the scaffold or at the stake was also part of the legal tradition of Germany in the eighteenth century. In Halberstadt, a town in Saxony a few miles from the present East German border, two women were tried in 1721; as a result, one of them was executed. The trial records, preserved in the Royal Prussian Secret Archives, were discovered and published in 1891 by F. C. Müller as a case history in a German journal of forensic medicine. The English translation that Brigitte Eriksson has prepared for this issue of the Journal of Homosexuality brings to life the tragic history of Catherina Margaretha Linck and her lover, another Catherine Margaret, whose surname was Mühlhahn. Their story has something of the fascination of a play by Bertolt Brecht in its humanity, bawdiness, comedy, pathos, and horror. There must be few court records that give us so full, vivid, and intimate a picture of the lives of any lesbian couple.

These records also show how eighteenth-century courts applied the legal, theological, and physiological principles we have traced in this essay. The chief Renaissance authority on Saxon law was Benedict Carpzow, or Carpzovius, whose monumental Practicae novae imperialis Saxonicae rerum criminalium was first published in 1652. Pars II, Quaestio 
LXXVI deals with penalties for sodomy. There Carpzov reprints section 116 of Charles V's Constitutions, which prescribed burning for men or women who had relations with their own sex. But Saxon law, he notes, is more specific. It differentiates three kinds of sodomy: first, masturbation, for which the penalty is "relegatio" (banishment); secondly, male and female homosexuality and sodomitical relations between men and women, which were punished by beheading; and, finally, bestiality, for which, as the most heinous crime, the penalty of burning is reserved.

It is interesting to see how lesbian cases were actually argued before the courts. Recognizing the legal importance of the Pauline tradition, Linck's defenders suggest (1) that Paul's words may have been limited in their reference to the one form of female sodomy for which the old testament did in fact provide the death penalty, that is, female bestiality; or, alternatively, (2) that what Paul may have had in mind was the kind of clitoral penetration African women were supposed to be capable of. (This second argument clearly echoes Sinistrari's treatise of 1700.) The court replied that according "to all the interpreters" Paul was indeed referring to lesbian relations in Romans I, 26, and that he may even have had in mind women who used instruments, since such devices were known to the Greeks, as Aristophanes' reference to olisboi shows. Though there is no emission of semen, mutual contact in an effort to achieve orgasm is enough to constitute the crime. Paul, by using general language, means to condemn all such relations. If he was writing against African practices, he did not intend to exclude others. Indeed, the African women at least used their natural members, while these depart farther still from nature. The guilt lies in the illicit sexual stimulus, and the emission of semen is irrelevant, though the court, in setting forth its reasoning in the case, notes a minority opinion that required emission. It is notable that though the court turns to Charles $V$ 's legislation and Saxon tradition when considering the punishment to be meted out, it is St. Paul's words that ultimately have the force of law in defining the nature of the offense.

Müller tells us that the recommended sentence of beheading was carried out. In Europe, later in the eighteenth century, homosexual men were also executed, though no further lesbian cases have come to light so far. Finally, however, the influence of the Enlightenment made itself felt. In 1791, the French National Assembly abolished sodomy as an offense between consenting adults, relegating it, in effect, to the same category as such archaic crimes as witchcraft, heresy, and blasphemy. This revolutionary reform was incorporated later into the Napoleonic Code. No executions of men or women are known to have taken place in continental Europe during the nineteenth century. In England hangings went on for another four decades, then ceased in 1835. A long nightmare had come to an end. 


\section{NOTES}

1. In 1811, however, a useful twenty-page compendium, with many legal and literary references, chiefly in Latin and French, was prepared for a famous Scottish libel case under the title "Authorities with Regard to the Practice of Tribadism." This has been reprinted in Jonathan Katz, ed., Miss Marianne Woods and Miss Jane Pirie against Dame Helen Cumming Gordon (New York: Arno Press, 1975).

2. Derrick Sherwin Bailey, Homosexuality and the Western Christian Tradition (London: Longmans, Green, 1955), p. 161.

3. Yebamoth 76a, trans. Isaac Slotki; in The Babylonian Talmud, 18 vols. (London: Socino Press, 1961), 8: 513.

4. Encyclopedia of Religion and Ethics, 1908-27 ed., s.v. "Hierodouli (Semitic and Egyptian): Hebrew," by George A. Barton.

5. Bailey, p. 74. 80.

6. Pierre Rapetti, ed., Li Livres de jostice et de plet (Paris: Didot Frères, 1850), pp. 279-

7. Sidney Lee, ed., The Boke of Duke Huon of Bordeaux, trans. Lord Berners. Early English Text Society, Series 2, vol. 40 (London: Trübner and Co., 1882), p. 727.

8. Bailey, p. 160.

9. St. John Chrysostom, The Homilies of S. John Chrysostom, Archbishop of Constantinople, on the Epistle of St. Paul the Apostle to the Romans, trans. J. B. Morris. Library of Fathers of the Holy Catholic Church, vol. 7 (Oxford: John Henry Parker, 1842), p. 47.

10. St. Ambrose, Omnia opera, 5 vols. in 3: Commentarii in omnes Pauli epistolas (Basel, 1567), 5: 178.

11. St. Anselm, In omnes sanctissimi Pauli apostoli epistolas enarrationes (Venice: ad signum spei, 1547), p. $8 \mathrm{v}$.

12. Peter Abelard, Commentarium super S. Pauli epistolam ad Romanos libri quinque, in Patrologia latina, ed. J.-P. Migne, 221 vols. (Paris: J.-P. Migne, 1844-66), 178: 806.

13. The only commentator I am aware of before the twentieth century who interprets Paul's words as referring to heterosexual sodomy is David Pareus in his Commentaria of 1608. Pareus is cited on page 26 of "The Additional Petition of Miss Mary-Ann Woods and Miss Jane Pirie" in the 1811 libel case (see note 1). In the same case, the "Answers for Dame Helen Cumming Gordon," page 21, rebuts this reading in favor of the standard lesbian interpretation with references to Tertullian, Clement of Alexandria, Hugo Grotius, Mathew Poole and James MacKnight. In contrast to commentators, lawyers defending lesbians in the courts did challenge the received interpretation, as in the 1721 German trial discussed below.

14. Bailey, pp. 103, 105.

15. Emil Friedberg and Emil Richter, eds., Corpus iuris canonici: Decretum magistri Gratiani, 2 vols. (Graz: Akademische Druk-U. Verlaganstalt, 1959), 2: 1144.

16. St. Thomas Aquinas, Summa theologica, trans. Fathers of the English Dominican Province, 3 vols. (New York: Benziger Brothers, 1947-48), 2: 1825.

17. Vern Bullough, Sexual Variance in Society and History (New York: John Wiley \& Sons, 1976), p. 353.

18. Paul Krueger and Theodor Nommsen, eds., Corpus iuris civilis: Codex Justinianus, 2 vols. (Frankfurt am Main: Verlag Weidmann, 1967), 2: 375.

19. Cino da Pistoia, In Codicem commentaria, 2 vols. (Frankfurt am Main: S. Feyerbrandt, 1578; reprint ed., Turin: Botega d'Erasmo, 1964), 2: 546A.

20. Bartholomaeus de Saliceto, Lectura super IX libris Codicis, 4 vols. (Lyons: Johannes Siber, 1496-1500), 4: no pagination. (Microfilm reprint, French Books before 1601, Lexington, Ky.: Erasmus Press, 1965, Roll 112.)

21. Hans Julius Wolff, Roman Law: An Historical Introduction (Norman, Okla.: University of Oklahoma Press, 1951). 
22. Bullough, p. 391 .

23. Henry Charles Lea, $A$ History of the Inquisition of Spain, 4 vols. (New York: Macmillan, 1907), 4: 361-71.

24. G. Ruggiero, "Sexual Criminality in the Early Renaissance," Journal of Social History 8 (1975): 18-37.

25. Clark L. Taylor, Jr., "El Ambiente: Male Homosexual Social Life in Mexico City" (Ph.D. dissertation, University of California at Berkeley, 1978), pp. 17-20. See also Taylor, "Mexican Gaylife in Historical Perspective," Gay Sunshine, no. 26/27, 1975-76, pp. 1-3.

26. E. William Monter, "La Sodomie à l'époque moderne en Suisse romand," Annales: E. S. C. 29 (1974): 1023-33. (A revised and updated translation of this essay, entitled "Sodomy and Heresy in Early Modern Switzerland," is included in this issue of the Journal of Homosexuality.)

27. Louis Crompton, "Gay Genocide: From Leviticus to Hitler," in The Gay Academic, ed. Louie Crew (Palm Springs, Calif.: ETC Publications, 1978), pp. 69-91; and A. Harvey, "Prosecutions for Sodomy in England at the Beginning of the Nineteenth Century," The Historical Journal 21 (1978): 939-48.

28. Arthur Gilbert, "Buggery and the British Navy, 1700-1861," Journal of Social History 10 (1976): 72-98.

29. Claude Courouve, "Sodomy Trials in France," Gay Books Bulletin 1 (1978): 22$23,26$.

30. See Monter, in this issue, note 7.

31. Leopold August Warnkönig, Flandrische Staats- und Rechtsgeschichte bis zum Jahr 1305, 3 vols. (Tübingen: L. F. Fues, 1839), 3(2): 76.

32. Rudolf His, Das Strafrecht des deutschen Mittelalters, 2 vols. (Weimar: Hermann Bohlaus Nachf., 1935), 2: 168. Claude Courouve has drawn my attention to a fuller account of this case in Theodor Hartster, Das Strafrecht der freien Reichsstadt Speier (Breslau: Marcus, 1900), pp. 184-85.

33. Antonio Gomez, Variae resolutiones, juris civilis, communis et regii (Venice: Typographia Remondiniana, 1758), p. 328.

34. Jean Papon, Recueil d'arrests notables des cours souveraines de France (Paris: Jean de la Fontaine, 1608), pp. 1257-58.

35. Henri Estienne, Apologie pour Hérodote, ed. P. Ristelhuber, 2 vols. (Paris: Isidore Lisieux, 1879), 1: 178. I am indebted to Lillian Faderman for directing me to this source, and to Sinistrari, below.

36. Michel Montaigne, The Diary of Montaigne's Journey to Italy in 1580 and 1581, trans. E. J. Trechmann (New York: Harcourt, Brace, 1929), p. 6.

37. J. Kohler and Willy Scheel, eds., Die peinliche Gerichtsordnung Kaiser Karls V: Constitutio criminalis Carolina (Halle an der Saale: Verlag der Buchhandlung des Waisenhauses, 1900), p. 62.

38. Statuta provisionesque ducales civitatis Tarvisii (Venice, 1574), pp. 187v-188.

39. Joseph Berní y Catalá, ed., Las siete partidas del rey D. Alfonso el Sabio, glossadas por el sr. D. Gregorio Lopez, 4 vols. (Valencia: Benito Montfort, 1767), 3: 178.

40. Abulensis is presumably Alonso Tostado, Bishop of Avila, who died in 1455.

41. Antonio Gomez, p. 328.

42. Benjamin Uroff, "Grigorii Karpovich Kotoshikhin, Russia in the Reign of Alexis Mikhailovich: An Annotated Translation" (Ph.D. dissertation, Columbia University, 1970), p. 217; Kotoshikhin, O Rosii v tsarstvovanie Alexseia Mikhailovicha, 4th ed. (St. Petersburg: Tipografiia Glavnago Upravlenia Udelov, 1906; reprint ed., Slavistic Printings and Reprintings, vol. 126, The Hague: Mouton, 1969), p. 116. I am indebted to Dr. Ann Kleimola for these references.

43. Louis Crompton, "Homosexuals and the Death Penalty in Colonial America," Journal of Homosexuality 1 (1967): 279. 
44. Ibid. Lillian Faderman has questioned whether we can be sure that the 1655 statute does indeed denote lesbian acts or whether it might refer instead to fellatio or to anal intercourse ("Lesbian Magazine Fiction in the Early Twentieth Century," Journal of Popular Culture 11 (1978): 814, note 4). It seems likely, however, that the framers did have lesbians in mind. First, as we have seen, ecclesiastical and legal authorities had customarily interpreted Paul's words as a reference to acts between women. As to oral relations, I am not aware of any law framed deliberately to include them before the late nineteenth century. And finally, in a later clause the statute makes it a crime to abuse "the contrary part of a grown woman," a provision that would not have been required if the earlier language had been intended to criminalize heterosexual anal relations.

45. Faderman, p. 814.

46. Nathaniel B. Shurtleff, ed., Records of the Colony of New Plymouth in New England, 12 vols. (Boston: William White, 1855-61), 2: 137, 163.

47. Ludovico Maria Sinistrari, De Delictis, et Poenis (Rome: Carlo Giannini, 1754), title 4, chapter 11 " "Sodomia"). This remarkable chapter, with 92 sections, is a major source of references for lesbianism and the law. A number of popular French and English translations have been published since 1883 under various titles (De la sodomie, Peccatum mutum, etc.), but with the legal references edited out of the text. These translations are listed in the National Union Catalogue.

48. Pierre-François Muyart de Vouglans, Institutes au droit criminel (Paris: Cellot, 1757), pp. 509-10.

49. Daniel Jousse, Traité de la justice criminel de France, 4 vols. (Paris: Chez Debure, 1771), 4: 122.

51. Ludovico Maria Sinistrari, De Delectis, et Poenis (Rome: Carlo Giannini, 1754), title 4, chapter 11 ("Sodomia"). This remarkable chapter, with 92 sections, is a major source of references for lesbianism and the law. A number of popular French and English translations have been published since 1883 under various titles (De la sodomie, PecPeccatum mutum, etc.), but with the legal references edited out of the text. These translations are listed in the National Union Catalogue.

52. Pierre-François Muyart de Vouglans, Institutes au droit criminel (Paris: Cellot, 1757), pp. 509-510.

53. Daniel Jousse, Traité de la justice criminel de France, 4 vols., (Paris: Chez Debure, 1771), vol. 4, p. 122. 